\title{
Population of Asian Corn Stem Borer (Ostrinia furnacalis) on F1 of Beauveria bassiana-Inoculated Corn
}

\author{
Itji Diana Daud $^{1 *}$, Sylvia Sjam ${ }^{1}$, Sari Bulang ${ }^{1}$, Mustika Tuwo ${ }^{2}$ \\ ${ }^{I}$ Department of Plant Pests and Diseases, Faculty of Agriculture, Hasanuddin University, Makassar 90245, Indonesia \\ ${ }^{2}$ Department of Biology, Faculty of Mathematics and Natural Sciences, Hasanuddin University, Makassar 90245, Indonesia \\ *Corresponding author. E-mail: itfir@yahoo.com
}

\begin{abstract}
Corn is a commodity in agriculture and Indonesian economic that has a multi-purpose function, both for food and feed. Corn in Indonesia is a major food staple and agricultural commodity after rice. One obstacle in effort to increase the productivity of corn is stem borer Ostrinia furnacalis which can attack plants in all phases of growth. Entomopathogenic application of Beauveria bassiana is an effort to control stem borer. The objective of the study is to observe $B$. bassiana still exist in FI seeds that grow as endophytic and the ability to infect stem borer on two corn varieties, Lamuru and Batara. Both varieties are F1 of B. bassiana endophytic-corn. The results showed that the number of larvae of $O$. furnacalis on the Lamuru variety was higher than Batara. Lamuru variety has higher infestation of $O$. furnacalis than Batara variety. The percentages of infected larvae by $B$. bassiana in Lamuru and Batara varities are 83\% (from 18 larvae) and 100\% (from 4 larvae), respectively.
\end{abstract}

Keywords: Batara, entomopathogenic, infection, Lamuru

\section{INTRODUCTION}

Corn is a strategic commodity in development of agriculture and Indonesian economic, that has a multipurpose function, both for food and feed. In recent years the proportion of corn use by the feed industry has reached $50 \%$ of the total national demand. The use of corn for feed is expected gradually to increase by $60 \%$ of the total national demand by 2020 [1]. Corn in Indonesia is a food staple and agricultural commodities after rice. Aside as the food staple corn is also as a national income. The increase of corn production become Indonesia government concern. The production and consumption should be balanced [2].

According to [3], the national corn production in 2019 will reach 33 million tons, up 9.8\% from the previous year. The challenge faced by Indonesia in increasing national corn production, both for food and animal feed, is to increase productivity by using good quality seeds and new improved varieties based on the suitable ecological land [4]. One of the obstacles to increase the corn productivity is Ostrinia furnacalis that can attack the all stage of corn growth [5-7].

Stem borer (Osrinia furnacalis Guenee.) is one of the major pests in corn plants. Corn stem borer larvae attack the leaves, stems, flowers, as well as cobs. The control techniques used are technical culture by simultaneous planting, intercropping, good soil management, biological control and chemical. Biological control is safer for the environment because it has no negative effects especially on non-target organisms. Efforts to control corn stem borer can be carried out by entomopathogenic Beauveria bassiana [8].

In this study, observations of $O$. furnacalis population were carried out on two corn varieties, Lamuru and Batara, treated with Beuvaria bassiana endophytic. Lamuru variety released by the Agency for Agricultural Research in 2000 was designed to be cultivated in dry land and climate conditions, such as East Nusa Tenggara, West Nusa Tenggara, and Central Sulawesi.

Lamuru variety contains $81 \%$ protein, Lysine $0.225 \%$ and tryptophan $0.050 \%$. The content of Lysine and Tryptophan in Lamuru variety were twice higher than the ordinary corn $[9,10]$. The hybrid variety of Batara variety has a strong root, resistant to downy mildew and leaf blight, and suitable on sub-optimal lands. The potential production of Bartara variety is 12.9 ton/ha. The aim of this research to evaluate two varieties against existence F1 B. bassiana as endophytic in seed corn.

\subsection{Materials and Methods}

\subsubsection{F1 Endophytic B. bassiana Preparation}

After land clearing, 2 plots of $2 \mathrm{~m}$ x $10 \mathrm{~m}$ treatment plots were made. The distance between plots was $1 \mathrm{~m}$. As many as 2 seeds per hole were planted with the planting space of 75 $\mathrm{cm} \times 25 \mathrm{~cm}$.

The corn seeds used were F1 endophytic seeds of Batara (B) and Lamuru (L) varieties. The F1 endophytic seed 
obtained from the parental plant. The seed of parental plant has been treated with B. bassiana. Both Batara and Lamuru varieties were planted in experimental garden of Moncong Loe Sub-District, Maros District, Central Sulawesi in JuneNovember 2014.

\subsubsection{Observations}

Study was carried out starting at 35 days after planting (DAP). The observation was carried out for 9 times with 3 days interval. Plant sampling was collected diagonally. There were 20 plant samples for each variety and 5 parameters to observe. The observation about percentage of plant infested by $O$. furnacalis, persentages of $O$. furnacalis larvae infected with $B$. bassiana, isolation and identification of $B$. bassiana in $O$. furnacalis cadaver.

\subsubsection{Ostrinia furnacalis observation and collecting}

Observations of larvae and pupae populations were carried out by observing the typical damage caused by the larvae: holes in the stem, transverse scrapings, old (dark brown) corncob hair, larvae inside the cob. Larvae and pupae inside the stem were examined by carefully cutting and dividing the stem segment $O$. furnacalis larvae found in the corn crop were collected then reared and fed as needed and deceased.

\subsubsection{Fungus isolation}

The dead $O$. furnacalis larvae were firstly sterilized. The larvae were soaked in Sodium hypochlorite $(\mathrm{NaOCl})$ for $3 \mathrm{~min}$ then washed using distilled water three times for one minute, then placed on filter paper. The fungus that grew on the larvae, was transferred on to PDA media to be purified (Figure 2).

PDA was made of $200 \mathrm{~g}$ potatoes, agar $17 \mathrm{~g}, 20 \mathrm{~g}$ sugar, and $1000 \mathrm{ml}$ distilled water. In the first stage, the potato was washed and cut into cubes, weighed $200 \mathrm{~g}$ and then boiled with $1000 \mathrm{ml}$ of distilled water. Potato boiled water was filtered and then the water was taken out and put into an Erlenmeyer containing sugar and agar that had been dissolved with a little distilled water. Distilled water was added to $1000 \mathrm{ml}$. To prevent contamination, $500 \mathrm{mg}$ chloramphenicol antibiotics were added. Then it was heated on a hot plate while stirring until it boils. Erlenmeyer was then covered with aluminium foil and PDA was sterilized for $2 \mathrm{hr}$ in autoclave. After completed, the media was poured onto a petri dish.
Observation of the presence of $B$. bassiana was conducted under a microscope. The morphological of fungi such as colour, shape, colony growth, and conidia was performed according of Barnett and Hunter [11].

\subsection{Our Contribution}

This paper showed the population of $O$. furnacalis in endophytic B.bassiana corn plant, the percentage of their attack and identified the existence of $B$. bassiana in their larvae. The F1 endophytic $B$. bassiana corn in a new varieties that produce bay The University of Hasanudin. The result of dead O. furnacalis larvae from this study will support the recommendation of corn to be planted by farmers.

\subsection{Paper Structure}

The rest of the paper is organized as follow, Section 2 presents the result of observation in graphic and tables. The result also provided by photography of Isolation of B.bassiana in the cadaver of $O$. furnacalis on media PDA. Section 3 contains the conclusion of the paper.

\section{RESULTS AND DISCUSSION}

\subsection{Population of Larva O. furnacalis}

The highest number of $O$. furnacalis larvae was found in the Lamuru variety at the fifth observation as many as 5 larvae from 20 sample plants (Figure 1). Figure 1 showed that population $O$. furnacalis was found at the age of 38 DAP for Lamuru variety, while for Batara variety was not yet found until 47 DAP. This was also thought to be caused by physiological and morphological factors of corn varieties. At the age of 50-59 DAP, it was seen that the $O$. furnacalis larvae attacked Batara variety and the attack rate decreased gradually. This was due to $O$. furnacalis could not find suitable hosts and food sources that were suitable for growth and development, hence the population was declining. According to [12], environmental factors play an important role in determining level of pest population, one of which is food. The availability of suitable food will cause a rapid increase in pest populations. 


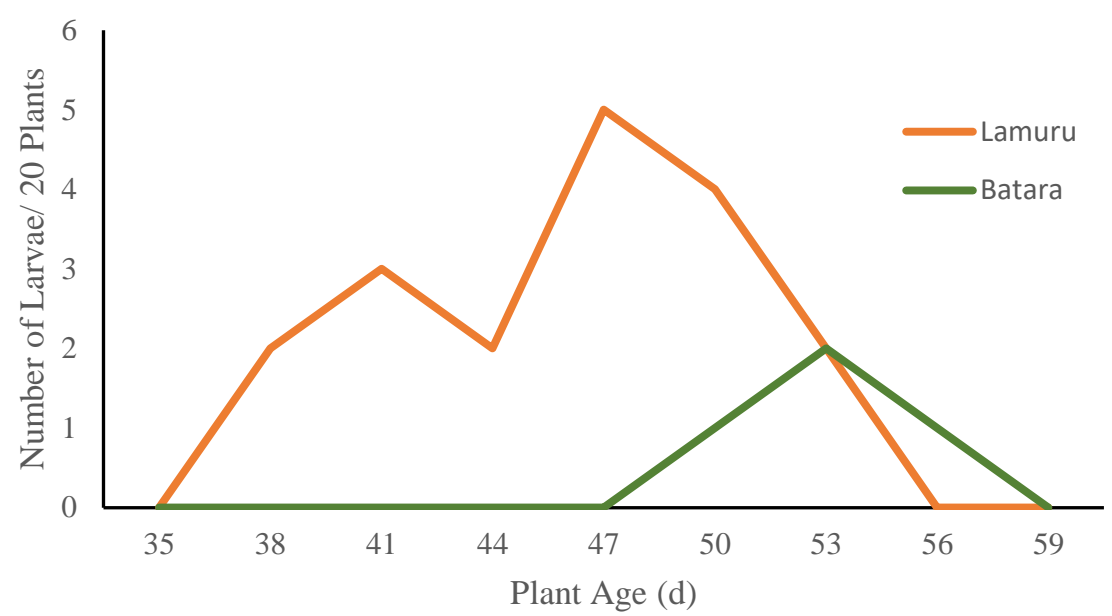

Figure 1 Number of larvae of $O$. furnacalis at each observation

\subsection{Percentage of Infested Plants by Larvae $O$. furnacalis}

Based on observations, the percentage of plants infested by $O$. furnacalis larvae in the Lamuru variety was higher than the Batara.

Table 1 Percentage of plants infested by Ostrinia furnicalis larvae at each observation

\begin{tabular}{|c|c|c|}
\hline Observation & \multicolumn{2}{|c|}{ Varieties } \\
\hline & Lamuru (\%) & Batara (\%) \\
\hline 1 & 0 & 0 \\
\hline 2 & 10 & 0 \\
\hline 3 & 15 & 0 \\
\hline 4 & 10 & 0 \\
\hline 5 & 25 & 0 \\
\hline 6 & 20 & 5 \\
\hline 7 & 10 & 10 \\
\hline 8 & 0 & 5 \\
\hline 9 & 0 & 0 \\
\hline
\end{tabular}

Lamuru variety had been infested by $O$. furnacalis since the second observation as many as $10 \%$ (Table 1). Meanwhile, Batara variety was infested since the sixth observation with the percentage of $5 \%$. The highest percentage of infested plants by $O$. furnacalis was found in Lamuru variety at fifth observation as many as 25\% (Table 1). Stem borer attacks Lamuru faster and more than Batara. The assumption that can be stated that Lamuru is a host that is preferred over Batara, but the presence of B. bassiana as endophytes in both varieties can infect stem borer.

\subsection{Percentage of Larvae Infected with $B$. bassiana}

Table 2 showed that the total number of $O$. furnacalis larvae found in Lamuru variety was higher than in Batara variety. The number of $O$. furnacalis larvae found in Lamuru varietiy was 18 which $15(83 \%)$ of them were infected with B. bassiana and 3 were uninfected (Table 2). Whereas in Batara was found as many as 4 larvae and all of them (100\%) were infected with $B$. bassiana (Table 2). Beauveria bassiana in the stem tissue is capable of infecting stem borer very well.

Table 2 Percentage of Ostrinia furnacalis larvae infected with Beauveria bassiana

\begin{tabular}{|c|c|c|c|}
\hline \multirow[b]{2}{*}{ Varieties } & \multicolumn{2}{|c|}{ Number of larvae } & \multirow{2}{*}{$\begin{array}{c}\text { Percentage } \\
\text { of infected } \\
\text { larvae }\end{array}$} \\
\hline & Infected & $\begin{array}{c}\text { Not } \\
\text { infected }\end{array}$ & \\
\hline Lamuru & 15 & 3 & $83 \%$ \\
\hline Batara & 4 & 0 & $100 \%$ \\
\hline
\end{tabular}

\subsection{Isolation and Identification of Beauveria bassiana Fungi}

The dead $O$. furnacalis larvae due to infection showed that the larvae was initially blackish brown and after a few days they were covered with white mycelium-like flour as mentioned (Figure 2). The infected host usually occurs colour changes and then black spots start to appear on the cuticle as the initial infection. Eventually the infected larvae would be dead and covered with fungal colony that resembles as mummy. Conidia of $B$. bassiana were 
gathered at the end of colony. Conidium was single-celled, oval and round.

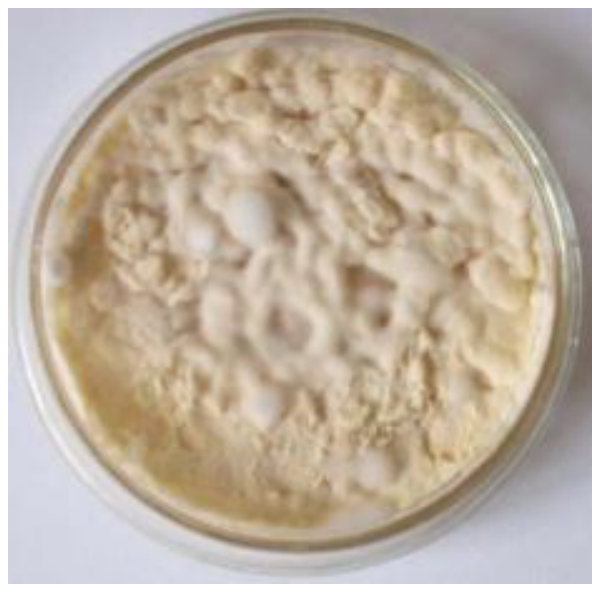

Figure 2 Fungi Beauveria bassiana from death larvae on PDA media

The mechanism of infection starts from attaching conidia to the insect cuticle, then germinates and grows in its host body. Germination of fungus conidia both in the insect integument and in artificial media generally requires certain nutrients, such as glucose, glucosamine, chitin, flour, and nitrogen, especially for hyphal growth [13]. Apart from contact, B. bassiana can also infect insects through inoculation or food contamination. tated that $37 \%$ of conidia of $B$. bassiana mixed with fire ant food Solenopsis richteri, germinated in the digestive tract within $72 \mathrm{hr}$, while hyphae were able to penetrate the intestinal wall between 60-72 hr. In the host's body this fungus quickly reproduces itself until the entire insect tissue is infected. Insects that have been infected with $B$. bassiana will usually stop eating, so they become weak, and death can be faster.

Generally, entomopathogenic fungi need a humid environment to be able to infect insects, therefore the epizootic in nature is usually formed when conditions are humid or wet. The effectiveness of B. bassiana infects pest insects depends on the species or strain of fungi, and the sensitivity of the insect stage to the level of environmental humidity, soil structure (for insects in the soil), and the right temperature. In addition, contact must be made between $B$. bassiana spores that are dispersed by the wind or carried by water with the host insect to cause infection. epizootic fungi that are formed naturally effectively control aphid populations, parasites which attack plant roots, grasshoppers, and thrips, as well as potential as a major mortality factor for aphids that attack potatoes and other host plants [13].

\section{CONCLUSION}

Lamuru variety has higher infestation of Ostrinia furnacalis than Batara variety. The percentages of infected larvae by Beauveria bassiana in Lamuru and Batara varieties are $83 \%$ and $100 \%$, respectively. F1 Corn containing B. bassiana in Batara varieties was still effective on O.furnacalis.

\section{ACKNOWLEDGMENT}

The authors would like to thank the Ministry of Research, Technology and Higher Education of the Republic of Indonesia for financial support through Riset Andalan Perguruan Tinggi dan Industri (Rapid) 2014-2016, administered by the Institute of Research and Community Services (LPPM), Hasanuddin University, Makassar, Indonesia.

\section{REFERENCES}

[1] Agricultural Research and Development Agency, General guidelines for corn PTT, Ministry of Agriculture, Agricultural Research and Development Agency, 2016

[2] Syamsuddin, Rahmawati, Production trends and development targets support sustainable corn selfsufficiency in South Sulawesi, Proceedings of the National Cereals Seminar 2015, pp. 649-660

[3] Kementerian Pertanian, Berapa Produksi dan Volume Impor Jagung Nasional, Kementan, 2019

[4] Kementerian Perdagangan Republik Indonesia, Laporan Akhir Analisis Pasok Jagung Sebagai Bahan Baku Pakan Ternak, Kemendag, 2016.

[5] D. Baco, J. Tandiabang, The main pest of corn and its control Maros Food Crops Research Institute. Balitsereal, 2015, http://litbang.pertanian.go.id

[6] A.N. Adnan, The main pest management technology for corn, Proceedings of the National Cereal Seminar, 2009, pp. 454-469

[7] M.S. Pabbage, A.N. Adnan, N. Nonci, Pengendalian Hama Pasca Panen pada Tanamn Jagung. Pusat Penelitian Tanaman Jagung Maros , Buletin Hasil Penelitian . 2007

[8] M. Lihawa, Witjaksono, N.S. Putra, Survey penggerek batang dan musuh alami pada tanaman Jagung di Provinsi Gorontalo. JPTI 16 (2) (2010) 81-87 
[9] H.G Yasin, M. Fatimawati, S.M. Made, K. Firdaus, Peranan Jagung Promunggi Terhadap Sistem Perjagungan Nasional., 2005

[10] M.B. Nappu, Herniwati, Appearance of superior varieties of sukmaraga and lamuru composite corn as seed sources in paddy fields, National Cereals Seminar, 2011, pp. 206-212

[11] H.L. Barnett, B.B. Hunter, Illustrated genera of imperfect fungi, 3rd Ed, Burges Publishing Co., Minesota, 1972

[12] Syarkawi, Effect of altitude on the level of cocoa pod borer (Conomorpha cramella Snellen) Attack in Pidie district, J. Floratek 10 (2) (2015) 52-60.

[13] D. Soetopo, I. Indrayani, Technology Status and Prospects of Beauveria bassiana for pest control of environmentally friendly plantation crops, Perspektif 6(1) (2007) 29-46. 